\title{
Angiopoietin-2-Driven Vascular Remodeling in Airway Inflammation
}

\author{
Sebastien P. Tabruyn, ${ }^{*}$ Katharine Colton, ${ }^{*}$ \\ Tohru Morisada, ${ }^{*}$ Jonas Fuxe, ${ }^{\dagger}$ \\ Stanley J. Wiegand, ${ }^{\ddagger}$ Gavin Thurston, ${ }^{\ddagger}$ \\ Anthony J. Coyle,,$^{\S}$ Jane Connor, \\ and Donald M. McDonald*

\begin{abstract}
From the Cardiovascular Research Institute, Comprehensive Cancer Center, and Department of Anatomy, University of California, San Francisco, California; the Department of Medical Biochemistry and Biophysics, ${ }^{\dagger}$ Matrix Biology, Karolinska Institute, Stockholm, Sweden; Regeneron Pharmaceuticals, Tarrytown, New York; and MedImmune LLC,, Gaithersburg, Maryland
\end{abstract}

Vascular remodeling is a feature of chronic inflammation during which capillaries transform into venules that expand the region of the vasculature in which leakage and leukocyte emigration both occur. Recently, we found that angiopoietin/Tie2 receptor signaling drives the transformation of capillaries into venules at an early stage of the sustained inflammatory response in the airways of mice infected with Mycoplasma pulmonis. However, the precise contributions of both angiopoietin-1 (Ang1) and angiopoietin-2 (Ang2) are not clear. In this study, we sought to determine the contribution of Ang2 to this vascular remodeling. Ang2 mRNA expression levels increased and phosphorylated Tie2 immunoreactivity in mucosal blood vessels decreased, indicative of diminished receptor signaling after infection. Selective inhibition of Ang2 throughout the infection by administration of either of two distinct functionblocking antibodies reduced the suppression of Tie2 phosphorylation and decreased the remodeling of mucosal capillaries into venules, the amount of leukocyte influx, and disease severity. These findings are consistent with Ang2 acting as an antagonist of Tie 2 receptors and the reduction of Tie 2 phosphorylation in endothelial cells rendering the vasculature more responsive to cytokines that promote both vascular remodeling and the consequences of inflammation after M. pulmonis infection. By blocking such changes, Ang2 inhibitors may prove beneficial in the treatment of sustained inflammation in which vascular remodeling, leakage, and leukocyte influx contribute to its patho- physiology. (Am J Pathol 2010, 177:3233-3244; DOI: 10.2353/ajpath.2010.100059)

Vascular remodeling is a well-documented feature of chronic inflammatory airway diseases such as asthma and chronic bronchitis. ${ }^{1-4}$ Such persistent inflammatory conditions are accompanied by changes in the molecular phenotype of endothelial cells and in the structure and function of blood vessels that contribute to the pathophysiology. ${ }^{5}$

Vascular endothelial growth factor (VEGF) and other growth factors drive angiogenesis in tumors and macular degeneration. Less is known about cytokines that promote vascular remodeling in inflammation, where blood vessels can undergo phenotypic changes in the absence of sprouting angiogenesis. VEGF is not involved in the vascular remodeling that occurs soon after infection of the murine respiratory pathogen Mycoplasma pulmonis, ${ }^{6,7}$ but tumor necrosis factor- $\alpha$ (TNF- $\left.\alpha\right)$ and related cytokines are likely contributors. ${ }^{8,9}$

Angiopoietins (Ang1, 2, and 3 in mice and Ang1, 2, and 4 in human) are key regulators of vascular remodeling, maturation, and stability through effects on Tie2 receptor signaling in endothelial cells. ${ }^{10}$ Angiopoietins are also important regulators of inflammatory responses, ${ }^{11}$ but their precise roles are complex.

Supported in part by NIH grants HL-024136, HL-059157, and HL-096511 (D.McD.) from the National Heart, Lung, and Blood Institute. ST was also supported by a fellowship of the Belgian American Educational Foundation and a fellowship of the "Centre Anticancéreux" (University of Liege, Belgium).

Accepted for publication August 19, 2010

G.T. and S.W. are employees of Regeneron (Tarrytown, NY), and J.C. and A.C. are employees of Medlmmune (Gaithersburg, MD).

Supplemental material for this article can be found on http:// ajp.amjpathol.org.

Current address for S.T.: BMGG Unit, GIGA-R, University of Liège, 4000 Liege, Belgium; and for A.J.C.: Pfizer Inc, Cambridge, MA.

Address reprint requests to Donald M. McDonald, M.D., Ph.D., Department of Anatomy, University of California, 513 Parnassus Avenue, Room S1363, San Francisco, CA 94143-0452. E-mail: donald.mcdonald@ ucsf.edu. 
The conventional view is that Ang1 has anti-inflammatory properties and Ang2 has pro-inflammatory properties. Ang1 promotes endothelial cell stability by inducing Tie2 phosphorylation ( $\mathrm{p}-\mathrm{Tie} 2){ }^{12,13}$ Ang1 protects against airway inflammation and hyperreactivity in asthma, ${ }^{14,15}$ reduces thrombin-induced interleukin-8 production and neutrophil adhesion, ${ }^{16}$ and decreases VEGF-induced upregulation of inflammatory adhesion molecules. ${ }^{17}$ Ang2, which is dynamically regulated, can be rapidly released from endothelial cell Weibel-Palade bodies and can antagonize the action of Ang1 by binding Tie2 without inducing phosphorylation. ${ }^{18,19}$ Ang2 sensitizes endothelial cells to TNF- $\alpha$ and can exaggerate inflammatory responses. ${ }^{11,20}$

Under certain conditions, Ang2 can activate Tie2 like Ang1, instead of opposing the actions of Ang 1. ${ }^{21,22}$ As an example, overexpression of Ang2 results in microvascular enlargement similar to that found after Ang1 overexpression. ${ }^{23}$ Both Ang1 and Ang2 can also have pro-inflammatory effects. Induction of P-selectin translocation in endothelial cells, activation of PAF synthesis in endothelial cells, and promotion of neutrophil activation, adhesion, and chemotaxis are examples. ${ }^{24-27}$ The usual explanation of these diverse effects is that the actions of Ang1 and Ang2 on Tie2 are dose- and context-dependent.

In a previous report, we describe that Ang1 protein and Ang2 protein both accumulate in mouse airways after M. pulmonis infection and that neutralization of angiopoietins by soluble Tie2 decoy receptors that sequester Tie2 ligands reduces vascular remodeling in this setting of sustained airway inflammation. ${ }^{28}$ Because the soluble receptors neutralized all Tie2 ligands, the approach did not distinguish the contributions of Ang 1 from those of Ang2 and did not learn whether the angiopoietin proteins measured were intracellular or were free to act on endothelial cell Tie2 receptors.

In the present study we used M. pulmonis infection as a model of sustained inflammation to test the concept that Ang2 promotes vascular remodeling by suppressing Tie2 signaling, which thereby supports the pro-inflammatory actions of TNF- $\alpha$ and other cytokines. $^{7-9}$ Our approach was to compare, before and after infection, the amounts of Ang1 and Ang2 mRNA expression and Tie2 phosphorylation and to determine the Ang2-dependence of infection-related vascular remodeling, adhesion molecule expression, and leukocyte influx by inhibiting Ang2 with a selective functionblocking antibody.

We found distinctive changes involving Ang1, Ang2, and p-Tie2 after M. pulmonis infection: Ang1 mRNA expression decreased, Ang2 mRNA expression increased, and p-Tie2 immunoreactivity decreased in mucosal blood vessels. Importantly, selective inhibition of Ang2 during infection not only blocked the change in p-Tie2, but also reduced the vascular remodeling, leukocyte influx, and infection severity. These findings are consistent with Ang2 having a pro-inflammatory action in this model by promoting vascular remodeling.

\section{Materials and Methods}

\section{Model of Airway Inflammation in Mice}

Male pathogen-free C57BL/6 mice (Charles River, Hollister, CA), housed under barrier conditions, were anesthetized by intramuscular injection of ketamine $(10 \mathrm{mg} / \mathrm{kg})$ and xylazine $(20 \mathrm{mg} / \mathrm{kg})$ and then infected by intranasal inoculation of $50 \mu \mathrm{l}$ of broth containing $10^{6} \mathrm{CFU}$ of strain CT7 M. pulmonis organisms (derived from $\cup A B C T^{29}$ ), half of the dose into each nostril. ${ }^{30}$ Mice were studied 1 , 3,7 , or 14 days after inoculation. All experimental procedures were approved by the Institutional Animal Care and Use Committee of the University of California at San Francisco.

\section{Ang2 Function-Blocking Antibodies}

Function-blocking monoclonal anti-Ang2 antibody REGN145 (5 mg/kg, Regeneron) or monoclonal antibody (mAb) 3.19 .3 (10 mg/kg, Medlmmune $)^{31}$ or isotypematched control IgG antibody was injected intraperitoneally into mice every other day for 7 days beginning 1 day before infection. REGN145 is a human monoclonal antibody with an estimated equilibrium dissociation constant $(\mathrm{kDa})$ for native human Ang2 of about $50 \mathrm{pmol} / \mathrm{L}$ and inhibits Ang2 with approx 500-fold greater potency than it inhibits Ang1. REGN145 has similar specificity and potency for mouse angiopoietins (Thurston et al, unpublished results). The human monoclonal antibody 3.19.3 has a $\mathrm{kDa}$ for human Ang2 of $86 \mathrm{pmol} / \mathrm{L}$ and binds Ang2 with 500-fold or greater affinity than for Ang1. The EC50 value of $\mathrm{mAb} 3.19 .3$ was $478 \mathrm{pmol} / \mathrm{L}$ for human Ang2 and $>194 \mathrm{nmol} / \mathrm{L}$ for human Ang1 in a cell-based assay. Values for mouse angiopoietins were in the same range.

\section{Immunohistochemistry}

Mice were anesthetized and perfused through the left ventricle for 2 minutes with $1 \%$ paraformaldehyde in PBS, pH 7.4. Tracheas were removed, immersed in fixative for an additional 1 hour and stained as wholemounts. The following primary antibodies were used for immunohistochemistry: PECAM-1 (CD31, hamster antimouse PECAM-1, clone 2H8, 1:500, Fisher), P-selectin (CD62P, rat anti-mouse, BD Biosciences), CD11b (rat anti-mouse CD11b, clone M1/70; eBioscience), Tie2 (rat anti-mouse, Tek4, eBioscience), p-Tie2 (Y992, rabbit antimouse, R\&D Systems), and Ang2 (LS-B58, LifeSpan Biosciences). Secondary antibodies were conjugated to fluorescein isothiocyanate, Cy3, or Cy5 (Jackson ImmunoResearch, West Grove, PA). Tracheas from pathogen-free mice were compared to those from mice infected for 7 or 14 days by staining with of the antibodies, except $\mathrm{p}$-Tie2 and CD11b, where the staining was impaired by poor penetration into the thickened tracheal whole mounts. 


\section{Imaging}

Digital images were acquired with a Zeiss Axiophot fluorescence microscope equipped with single, dual, and triple fluorescence filters and a low-light, 3-chip, charge-coupled device (CCD) camera (CoolCam, SciMeasure, Decatur, GA, $640 \times 480$ pixel RGB-color). This camera also enabled real-time viewing and measuring of blood vessels using custom software. Confocal images were obtained with a Zeiss LSM-510 confocal microscope with Argon, Helium-Neon, and UV lasers $(512 \times 512$ or $1024 \times 1024$ pixel RGB-color) and AIM 3.2.2 software.

\section{Measurement of Vascular Remodeling}

The diameter of capillaries in the tracheal mucosa was measured at the rostro-caudal midpoint of cartilage rings, which was roughly halfway between the arteriole and venule. ${ }^{32}$ Five or more vessels were measured over each of 10 cartilage rings in each trachea while viewing realtime fluorescent images of $960 \times 1280 \mu \mathrm{m}$ regions of tissue $(\times 10$ objective, $\times 1$ Optovar).

\section{Measurement of Immunoreactivity}

Amounts of CD11b immunoreactivity of leukocytes and P-selectin immunoreactivity of blood vessels were measured in digital fluorescence images of regions of tracheal mucosa measuring $960 \times 1280 \mu \mathrm{m}(\times 10$ objective, $\times 1$ Optovar) over cartilage rings in tracheal wholemounts. Five regions were assessed in each trachea, beginning with the second cartilage ring caudal to the larynx and continuing consecutively toward the bronchi. Area density of CD11b or P-selectin immunoreactivity (red pixels) was calculated as the proportion of total pixels having a fluorescence intensity greater than background based on a threshold value of 20 in the range $0<$ 255 by using ImageJ software (http://rsb.info.nih.gov/ij). ${ }^{33}$ The overall mean for each group was calculated from the average of all values in each mouse.

\section{RNA Extraction and Quantitative Reverse Transcription-PCR}

RNA was isolated from tracheas using the RNeasy Plus Mini isolation kit (Qiagen). RNA yield and purity were determined by spectrophotometry. cDNAs were synthesized with $1 \mu \mathrm{g}$ of total RNA using the cDNA synthesis kit (Roche Applied Science). Quantitative reverse transcription (qRT) PCR was performed with Kapa SYBR Fast qRT-PCR master mix (Kapa Biosystems, Cambridge, MA) using a BioRad MylQ detection system (Bio-Rad). The relative expression of each target gene was normalized to the expression of $\beta$-actin by calculation of the difference between the Ct target and the Ct reference gene, where $\mathrm{Ct}$ is the fractional PCR cycle number at which the reporter fluorescence is greater than the threshold. The primers used were: M. pulmonis $16 \mathrm{~S}$ RNA: 5'-CCCTAAGTATGACGGTACCTTGTCA-3' and 5'-GCGGCTGCTGGCACAT-3'; TNF- $\alpha$ : 5'-GATCTCTCG-
GAACCTCATCG-3' and 5'-GGCTTCTTTCGCACAATCTC3'; CD11b: 5'-ATGGACGCTGATGGCAATACC-3'; P-selectin: 5'-GCATACTCATGGAATAACTCACG-3' and 5'GACGTCATTGAGGTGAGCG-3'; E-selectin: 5'-ATGCCTCGCGCTTTCTCTC-3' and 5'-GTAGTCCCGCTGACAGTATGC-3'; ang1: 5'-GCAAAGGCTGATAAGGTTATGA-3' and 5'-AGCTACCAACAACAACAGCA-3'; ang2: 5'-TTCTTCTTTACGGATAGCAAC-3' and 5'-AGCCACGGTCAACAACTCGC-3'; tie-2: 5'-GTTGACTCTAGCTCGGACTGT-3' and 5'-GAAGTCGAGAGGCGATCCC-3'; ve-cadherin: 5'-CACTGCTTTGGGAGCCTTC-3' and 5'-GGGGCAGCGATTCATTTTTCT-3'.

\section{Statistical Analysis}

Values are expressed as means \pm SEM with five mice per group except with indicated otherwise. All of the experiments were repeated twice. The significance of differences among groups was assessed by analysis of variance (analysis of variance) followed by the Dunn-Bonferroni posthoc test for multiple comparisons with differences considered significant where $P<0.05$.
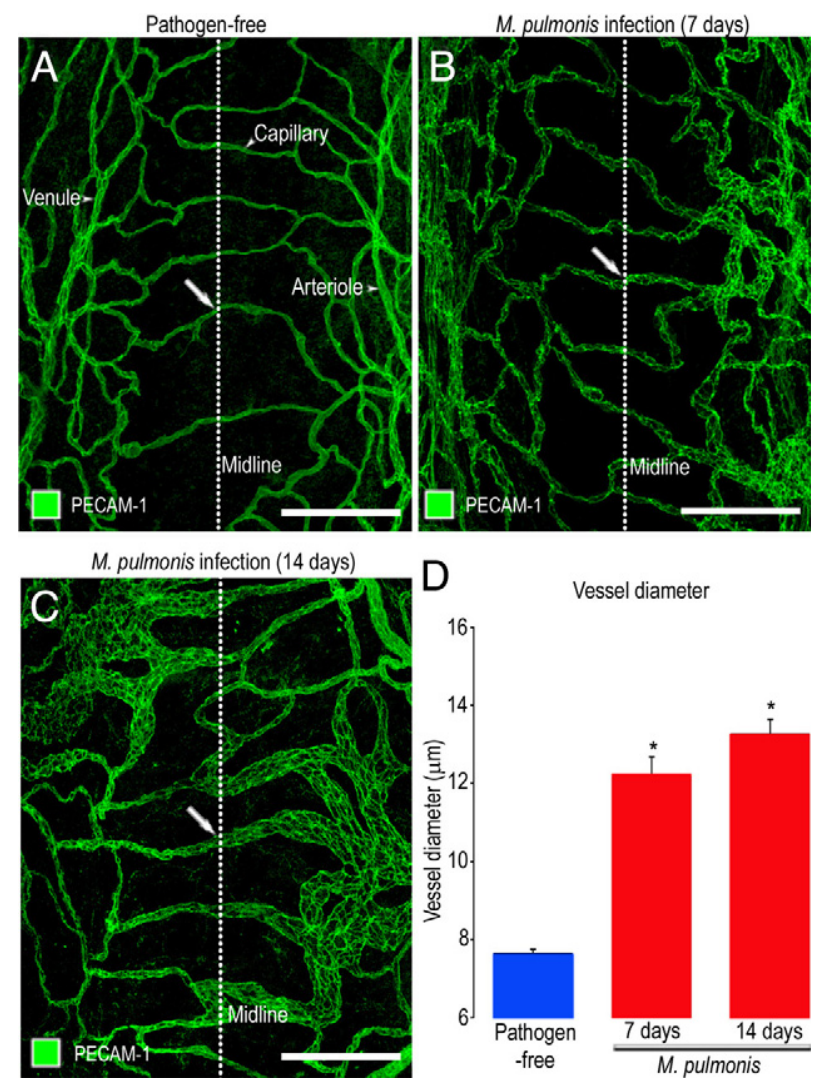

Figure 1. Vascular enlargement after $M$. pulmonis infection. A-C: Confocal microscopic images of blood vessels (green, PECAM-1) in tracheal whole mounts comparing capillaries in pathogen-free mouse (A, arrow) to enlarged, remodeled vessels (arrows) in mice infected with $M$. pulmonis for 7 days (B) or 14 days (C). D: Measurements of vessels at midpoint of cartilage ring (dotted line) show the magnitude of vascular enlargement after infection. ${ }^{*} P<0.05$ compared with pathogen-free. Scale bars $=100 \mu \mathrm{m}$ 

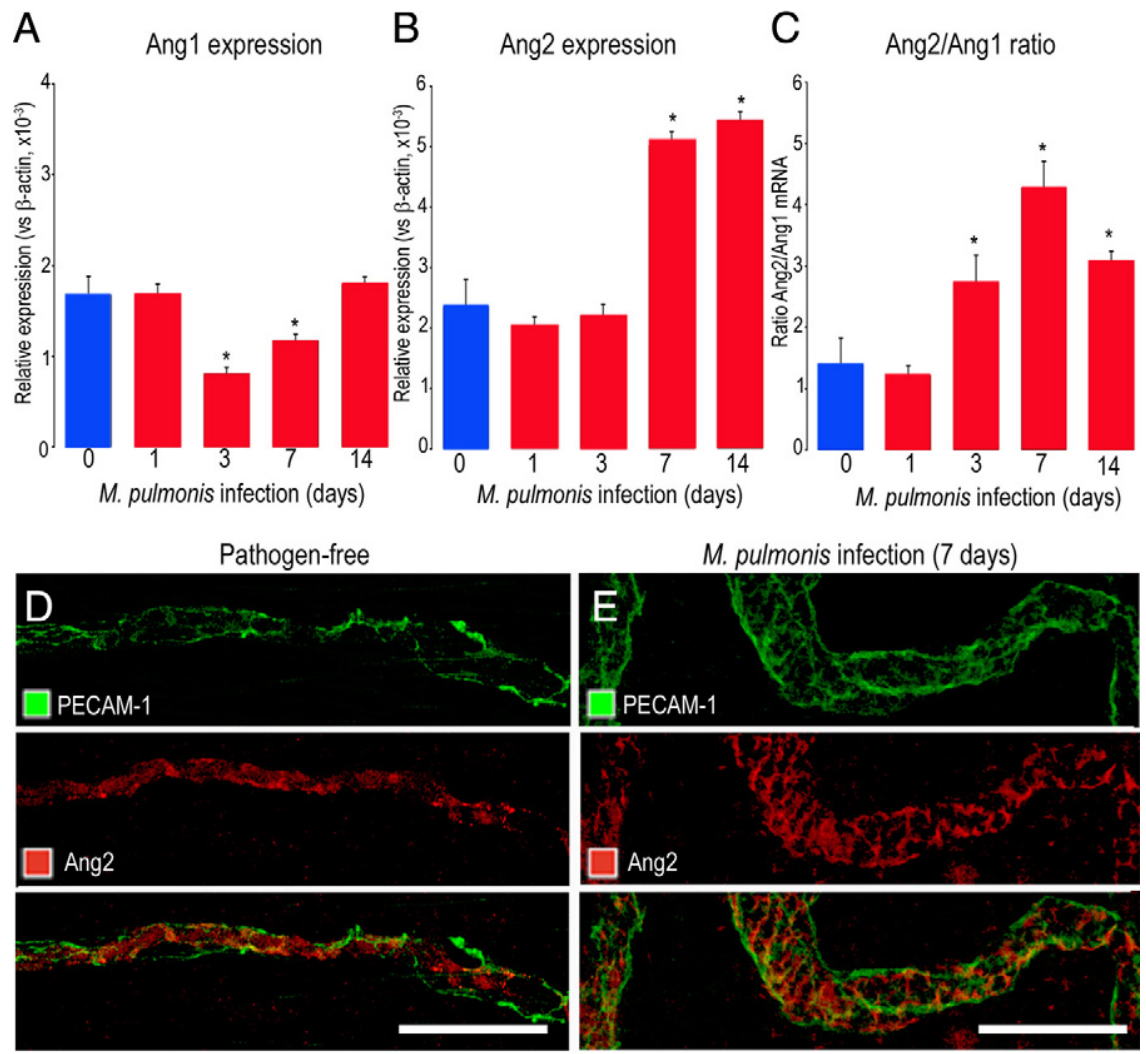

Figure 2. Increase in Ang2 expression after $M$. pulmonis infection. A and B: qRT-PCR measurements of expression of Ang1 mRNA (A) and Ang2 mRNA (B) in trachea of pathogen-free mice and mice infected with $M$. pulmonis for $1,3,7$, or 14 days. C: Ratio of qRT-PCR measurements of Ang2 mRNA to Ang1 mRNA. ${ }^{*} P<0.05$ compared to pathogen-free (day 0). D and E: Confocal micrographs of vessels in tracheal whole mounts showing Ang2 (red) and PECAM-1 (green) immunoreactivities of a capillary in a pathogen-free mouse (D) and a remodeled vessel over a cartilage ring in a mouse infected with $M$. pulmonis for 7 days (E) Scale bars $=30 \mu \mathrm{m}(\mathbf{D}$ and $\mathbf{E})$.

\section{Results}

\section{Vascular Remodeling after M. pulmonis Infection}

In the trachea of pathogen-free mice, capillaries over cartilaginous rings were organized in a distinctive ladderlike pattern (Figure 1A). Most arterioles and venules were located in regions of the mucosa between cartilage rings (Figure 1A). Conspicuous changes were evident in the tracheal vasculature after M. pulmonis infection. At 7 and 14 days after infection, capillaries were conspicuously enlarged but had no evidence of new blood vessel growth by sprouting angiogenesis (Figure 1, B-C). The diameter of the remodeled vessels was on average $60 \%$ greater than the pathogen-free value at 7 days after infection and $75 \%$ greater at 14 days (Figure 1D).

\section{Expression of Ang1 and Ang2 after M. pulmonis Infection}

Measurements by qRT-PCR of tracheas of pathogen-free mice revealed roughly equal amounts of Ang1 and Ang2 mRNA when expressed as copy number relative to $\beta$-actin (Figure 2, $A-C$ ). On days 3 and 7 after $M$. pulmonis infection, Ang1 mRNA expression was significantly less than in pathogen-free mice (Figure 2, A-B). Ang2 expression was unchanged on day 3 , but on day 7 was significantly greater than the pathogen-free value. At day 14 of infection, Ang1 expression was back to the baseline, but Ang2 remained increased (Figure 2B). Because of the early reduction in Ang1 and subsequent sustained increase in Ang2, the mRNA the ratio of Ang2 to Ang1 was significantly greater at 3, 7 and 14 days after infection (Figure 2C).

The distribution of Ang2 immunoreactivity in relation to PECAM-1 staining of blood vessels was assessed by immunohistochemical staining of tracheal whole-mounts before and after M. pulmonis infection. Ang2 immunoreactivity was found in capillaries of pathogen-free tracheas (Figure 2D) and in remodeled vessels at 7 days after infection, when capillaries had enlarged and acquired the phenotype of venules (Figure 2E). Because the remodeled vessels had a conical shape (Figure 1, $\mathrm{B}-\mathrm{C}$ ), those sampled near the midline (Figure 2E) were not as large as those downstream.

Ang2 immunoreactivity did not strictly colocalize with PECAM-1. Staining with the hamster anti-mouse PECAM-1 antibody was largely membrane-associated and strongest at endothelial cell borders. However, most Ang2 staining was not in the membrane but was instead cytoplasmic, presumably in Weibel-Palade bodies ${ }^{19}$ that could not be individually resolved in tracheal whole mounts. Therefore, PECAM-1 and Ang2 were associated with the same blood vessels but had slightly different distributions within the vessel wall.

\section{Distribution of Tie2 in Airway Vasculature}

Tie2 immunoreactivity was present throughout the vasculature of pathogen-free tracheas and largely matched the distribution of PECAM-1 (Figure 3A). The distribution and 


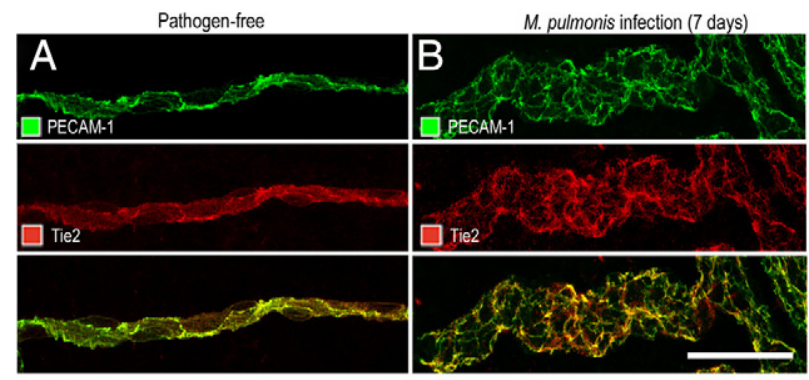

C
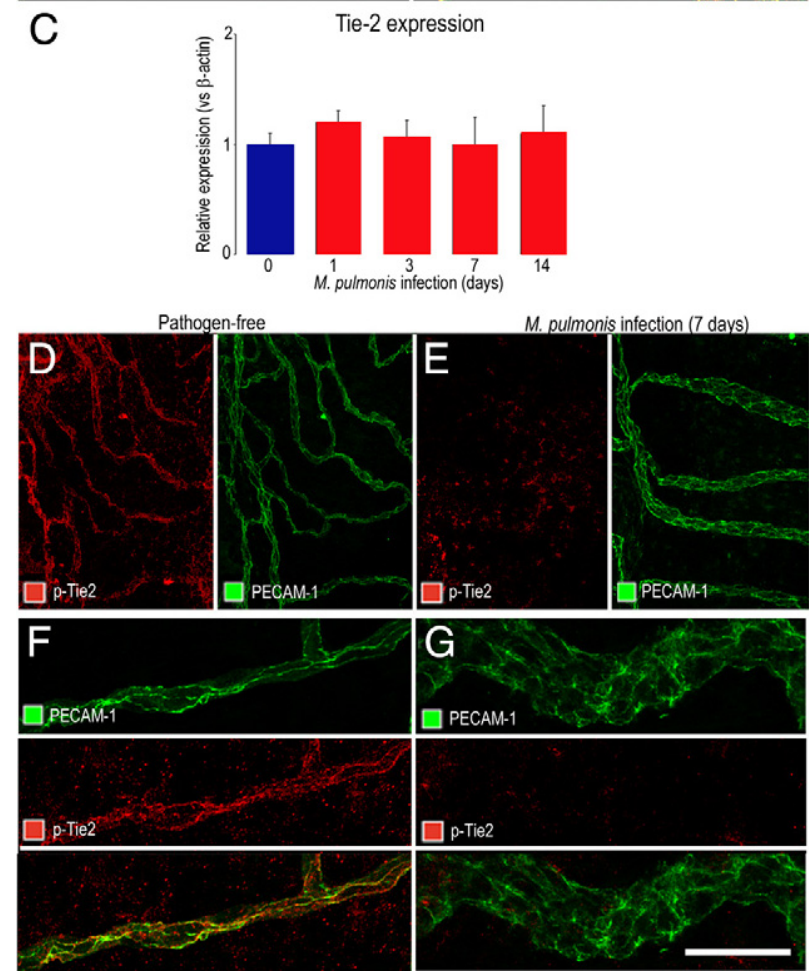

Figure 3. Decrease in Tie2 expression after $M$. pulmonis infection. A and B: Confocal micrographs showing the similarity of Tie2 (red) in tracheal capillary of pathogen-free mouse (A) and remodeled vessel in mouse infected for 7 days (B). PECAM-1, green. C: qRT-PCR measurements showing no difference in Tie- 2 mRNA, expressed relative to $\beta$-actin, in trachea of pathogen-free mice (day 0 ) and mice infected for $1,3,7$, or 14 days. D-G: Confocal micrographs at lower (D and $\mathbf{E}$ ) and higher (F and G) magnifications showing weaker p-Tie2 immunoreactivity (red) in remodeled vessels after infection for 7 days (E and $\mathbf{G})$ than in tracheal capillary of pathogen-free mouse ( $\mathbf{D}$ and $\mathbf{F}$ ). Images were acquired with the same fluorescence intensity setting. Scale bars: $30 \mu \mathrm{m}$ (A and $\mathbf{B}$ ); 100 $\mu \mathrm{m}$ (D and $\mathbf{E}) ; 30 \mu \mathrm{m}(\mathbf{F}$ and $\mathbf{G})$.

intensity of Tie2 immunoreactivity was about the same in remodeled blood vessels after $M$. pulmonis infection for 7 days (Figure 3B) or 14 days. Similarly, overall expression of Tie2 mRNA in the trachea was essentially unchanged after infection for 1 to 14 days (Figure 3C).

p-Tie2 immunoreactivity was clear and uniformly distributed in the vasculature of pathogen-free tracheas (Figure 3, D and F) but was faint or absent in the remodeled vasculature after 7 days of infection (Figure 3, E and G, and Supplemental Figure S1, at http://ajp. amjpathol.org), consistent with continued presence of Tie2 receptors in endothelial cells but reduced activation after infection.

\section{Reduction in Vascular Remodeling by Ang2 Blockade with REGN145}

The contribution of Ang2 to vascular remodeling after $M$. pulmonis infection was tested by administration of a function-blocking anti-Ang2 antibody, REGN145, throughout the infection. Tracheal capillaries in mice treated with REGN145 three times a week starting the day before infection were smaller at 7 days after infection than in mice treated with control IgG (Figure 4, A-C). Measurements revealed that the enlargement of blood vessels over cartilage rings after 7 days of infection was $70 \%$ less in mice treated with REGN145 than in mice treated with IgG (Figure 4D). Similarly, qRT-PCR measurements of expression of PECAM-1 and the endothelial cell-specific adherens junction protein VE-cadherin showed a significant increase after 7 days of infection in mice treated with control IgG, consistent with vascular enlargement, but not in mice treated with REGN145 (Figure 4, E and F). Similarly, the reduction in p-Tie2 immunoreactivity found after infection was less in mice treated with REGN145 (Figure 4, G and H). Together, these results fit with Ang2 blockade by REGN145 during infection leading to greater Tie2 activation and less vascular remodeling.

\section{Reduction in P-Selectin Expression by Ang2 Blockade with REGN145}

P-selectin immunoreactivity was not present in capillaries (arrows) in the trachea of pathogen-free mice (Figure 5A), and was faint in venules (arrowheads) of these mice. However, after $M$. pulmonis infection for 7 days, P-selectin was unusually strong in venules, including the remodeled vessels (arrow) over a cartilage ring where capillaries were normally located (Figure 5B). The change in vessel phenotype from capillary to venule fits with published evidence showing that the remodeled vessels acquire multiple markers of a venous identity (P-selectin, E-selectin, ICAM-1, EphB4). ${ }^{28}$

P-selectin staining was much weaker in the vasculature of infected mice treated with REGN145 (Figure $5 \mathrm{C}$ ). Measurements revealed that the 20 -fold increase in P-selectin immunofluorescence after infection was reduced by $70 \%$ when the infection was accompanied by REGN145 (Figure 5D). Similarly, tracheal expression of P-selectin mRNA was 10-fold greater after infection for 7 days and was reduced by $70 \%$ in infected mice treated with REGN145 (Figure 5E). Changes in expression of E-selectin (Figure 5F) were similar in magnitude.

\section{Reduction in Vascular Remodeling by Ang2 Blockade with mAb 3.19.3}

A second function-blocking anti-Ang2 antibody (mAb 3.19.3) gave results consistent with the effects of REGN145 and provided further support for the contribution of Ang2 to vascular remodeling after M. pulmonis infection. Vascular remodeling, reflected by increase in 

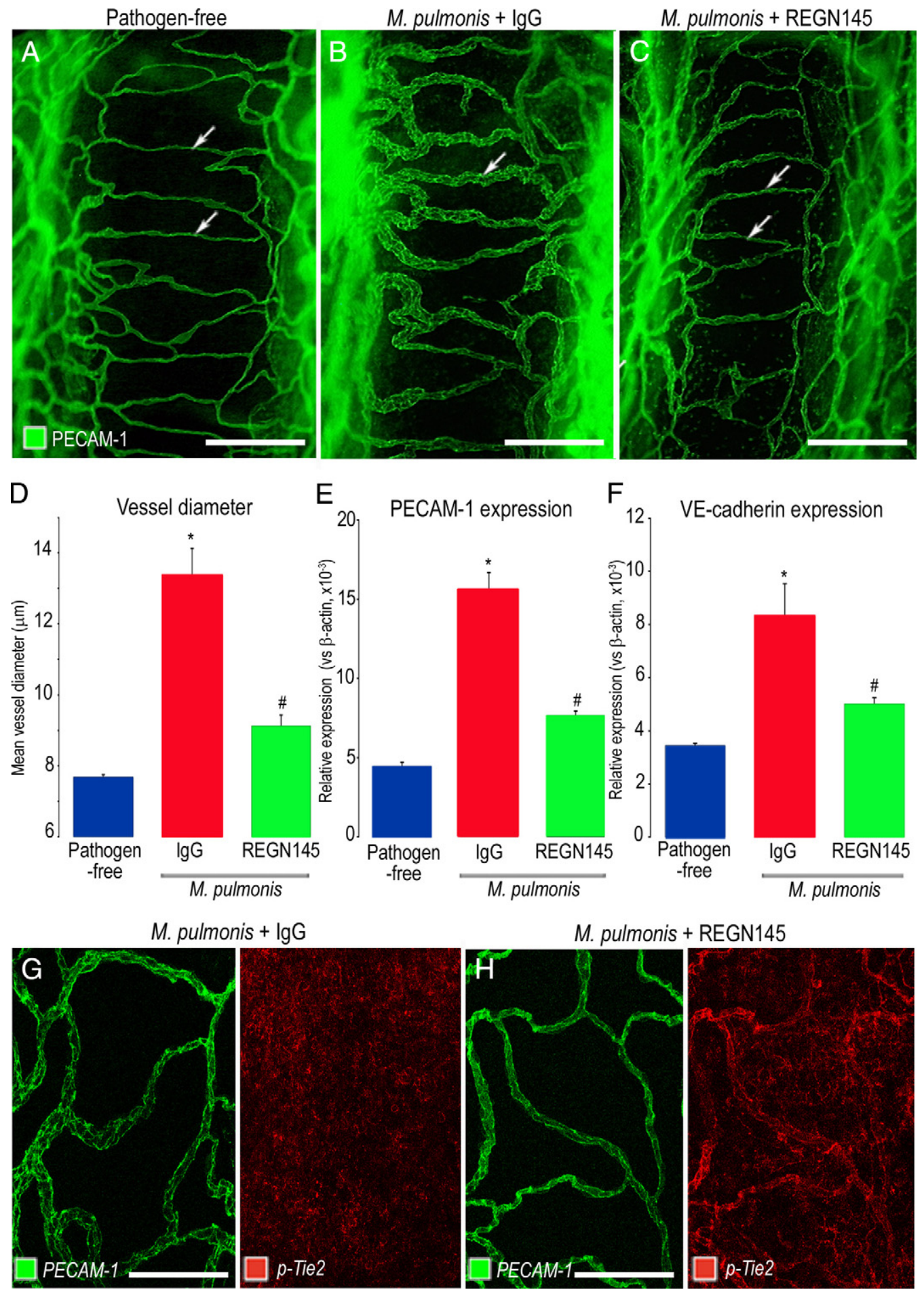

Figure 4. Reduction in vascular enlargement and p-Tie2 suppression by Ang2 blockade with REGN145. A-C: Confocal micrographs comparing the size of blood vessels (green, PECAM-1) in tracheal whole mounts from a pathogen-free mouse (A) and mice infected with M. pulmonis for 7 days with concurrent treatment with normal IgG (B) or REGN145 $5 \mathrm{mg} / \mathrm{kg}(\mathbf{C})$. Arrows mark blood vessel measurement site over midpoint of cartilage ring. D: Contrasting mean vessel diameters in tracheas of pathogen-free mice and infected mice treated with IgG or REGN145 for 7 days. E and F: qRT-PCR measurements of PECAM-1 (E) and VE-cadherin (F) in tracheas of pathogen-free mice and infected mice treated with IgG or REGN145 for 7 days. ${ }^{*} P<0.05$ compared to pathogen-free; ${ }^{*} P<0.05$ compared to infected mice treated with IgG. G and H: Pairs of confocal micrographs showing PECAM-1 (green) and p-Tie2 (red) immunoreactivities of tracheal blood vessels after infection for 7 days. p-Tie2 is faint or absent on vessels in infected mouse that received $\operatorname{IgG}(\mathbf{G})$ but is stronger on vessels in infected mouse treated with REGN145 (H). Scale bars: $150 \mu \mathrm{m}(\mathbf{A}-\mathbf{C})$ or $100 \mu \mathrm{m}(\mathbf{G}$ and $\mathbf{H})$.

vessel diameter and in P-selectin immunoreactivity after infection, was greater in mice treated with the control IgG than in corresponding mice treated with the Ang2 inhibitor mAb 3.19.3 (Figure 6, A-C). Measurements showed that the amount of vessel enlargement was $50 \%$ less when the infection was accompanied by mAb 3.19.3 (Figure 6D). Similarly, qRT-PCR measurements of expression of PECAM-1, VE-cadherin, P-selectin, and E- 

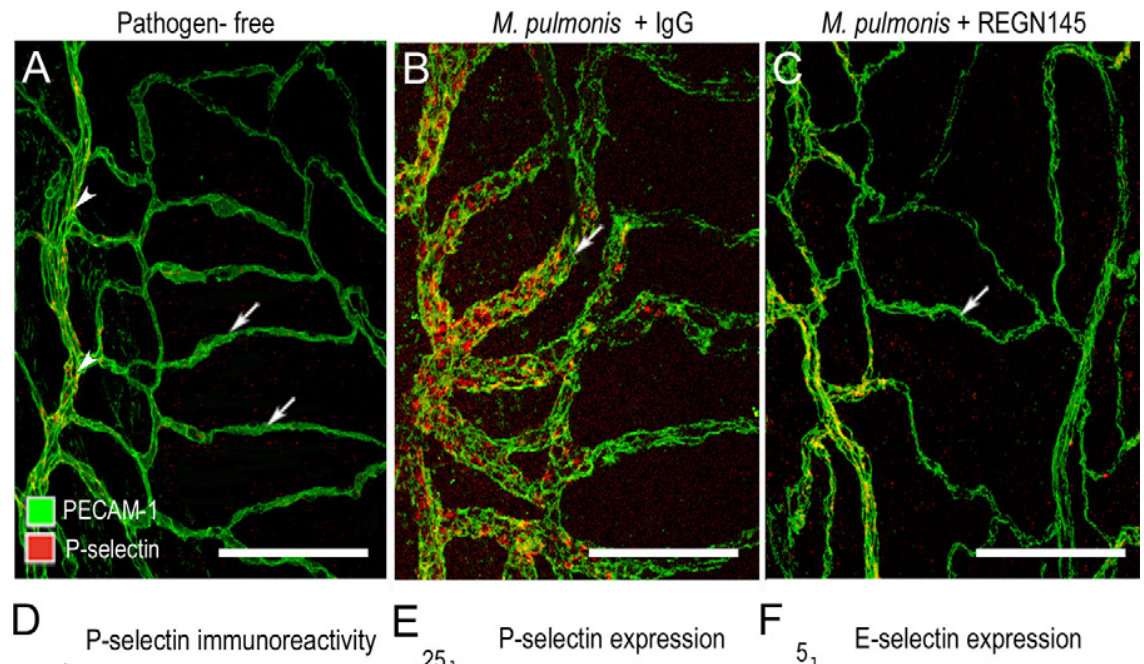

$\mathrm{E}$

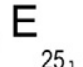

P-selectin expression

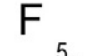

E-selectin expression
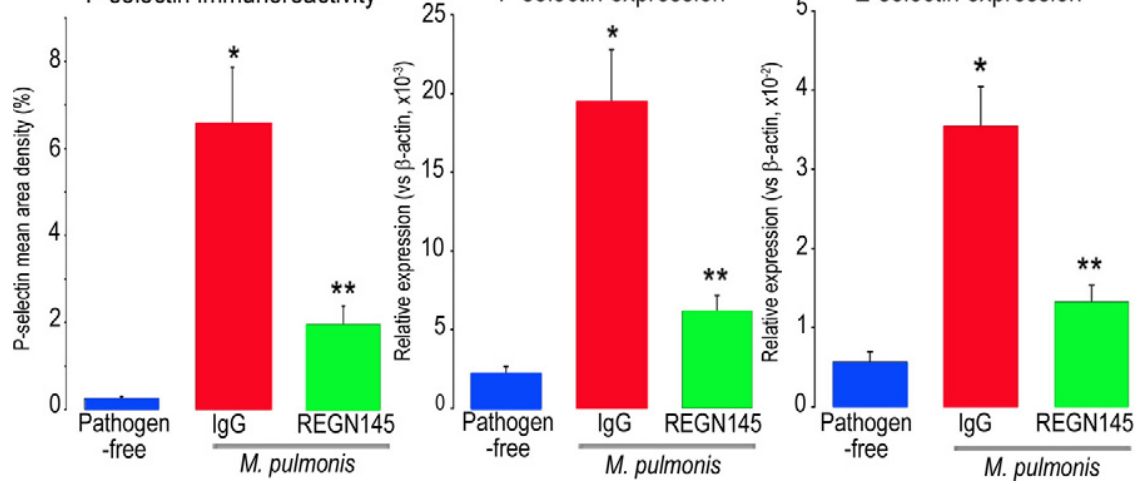

Figure 5. Reduction in adhesion molecule expression by Ang2 blockade with REGN145. A-C: Confocal micrographs of P-selectin immunoreactivity (red) in blood vessels (green, PECAM-1) of tracheal whole mounts. P-selectin immunoreactivity in pathogen-free trachea $(\mathbf{A})$ is absent in capillaries (arrows) and faint in venules (arrowhead). After $M$. pulmonis infection, P-selectin is strong in remodeled vessels (arrow) of mouse treated with IgG (B) but weak in vessels (arrow) of mouse treated with REGN145 at a dose of $5 \mathrm{mg} / \mathrm{kg}(\mathbf{C})$. D: Fractional area of P-selectin immunoreactivity in regions of vessels over cartilage in pathogen-free mice and in infected mice treated concurrently with IgG or REGN145. E and F: qRT-PCR measurements comparing expression of P-selectin (E), and Eselectin (F) mRNA in tracheas of pathogen-free and infected mice treated with IgG or REGN145 for 7 days. ${ }^{*} P<0.05$ compared to pathogen-free ${ }_{* *}^{*} P<0.05$ compared to infected mice treated with IgG. Scale bars $=150 \mu \mathrm{m}$. selectin were about $75 \%$ lower in infected mice treated with $\mathrm{mAb}$ 3.19.3 than with IgG (Figure 6, E and F).

\section{Reduction in Leukocyte Influx and Infection Severity by Ang2 Blockade}

The number of CD11b-positive cells in the tracheal mucosa was used to determine whether increased expression of P-selectin and E-selectin on remodeled blood vessels after $M$. pulmonis infection was accompanied by greater leukocyte influx. In pathogen-free tracheas, CD11b immunoreactive cells were sparse, and most around venules in intercartilaginous regions (Figure 7A). By comparison, at 7 days after infection, CD11b-positive cells were abundant throughout the trachea (Figure 7B, control IgG), but when Ang2 was inhibited by REGN145 during the infection, fewer leukocytes were located in the mucosa over cartilage rings (Figure 7C). CD11b immunoreactivity in these regions was $70 \%$ less in infected mice treated with REGN145 than in those treated with IgG (Figure 7D). CD11b RNA expression measured by qRTPCR was significantly lower in infected mice treated with REGN145 than in mice treated with the control IgG (Figure $7 \mathrm{E}$ ). Expression of TNF- $\alpha$ was also significantly lower in REGN145-treated mice (Figure 7F).

Infection severity was also assessed by qRT-PCR measurements of expression of $M$. pulmonis 16S rRNA in the trachea (Figure 7G). The amount of $M$. pulmonis $16 \mathrm{~S}$ rRNA was strongly correlated with P-selectin expression as an index of vascular remodeling $\left(R^{2}=0.894, P<\right.$ 0.01 ). Amount of $M$. pulmonis $16 \mathrm{~S}$ rRNA was significantly less in infected mice treated with REGN145 or with mAb 3.19.3 than with IgG, consistent with reduced overall severity of infection (Figure $7 \mathrm{H}$ ).

\section{Discussion}

The present study sought to determine whether Ang2 drives vascular remodeling in the respiratory tract after M. pulmonis infection. The remodeling results from endothelial cell proliferation-not vasodilatation or sprouting angiogenesis_-and leads to circumferential enlargement of capillaries. ${ }^{30,34}$ In the process, capillaries acquire a venular phenotype, reflected by increased immunoreactivity for multiple molecules typical of venules, including P-selectin, E-selectin, ICAM-1, and EphB4, that supports leukocyte adherence and migration and other venulespecific features of the inflammatory response. ${ }^{28,34,35}$ Gene expression arrays have documented the increase in expression of leukocyte adhesion molecules at 1 and 12 weeks after infection (at 1 week: P-selectin, 10-fold; E-selectin, 43-fold; and ICAM-1 fourfold compared to pathogen-free; McDonald and Thurston, unpublished data).

Previous reports have shown the importance of Tie2 signaling in blood vessel remodeling and stabilization $^{13,36}$ and have implicated angiopoietins as factors 

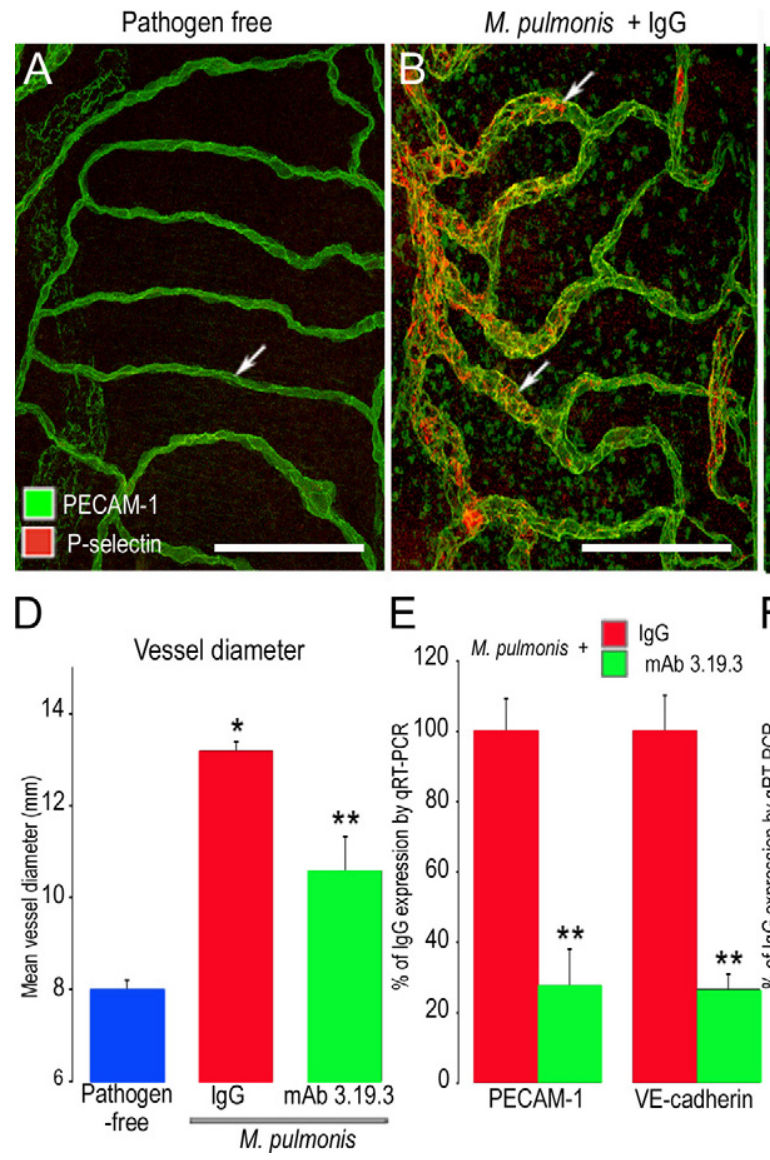

that drive remodeling of blood vessels and lymphatics during development ${ }^{37,38}$ and after $M$. pulmonis infection. ${ }^{5,28,39}$ Angiopoietins are also thought to play a role in other models of injury and inflammation. ${ }^{14,20,40}$ However, uncertainties regarding the relative contributions of Ang1 and Ang2 to vascular remodeling in inflammation warranted further studies and led to our use of multiple readouts to assess changes in angiopoietins and Tie2 signaling in mouse airways after M. pulmonis infection.

Our experiments revealed that the vascular remodeling present after $M$. pulmonis infection for 7 days was accompanied by increased Ang2 mRNA expression, when Ang2 immunoreactivity was largely restricted to endothelial cells. Immunoreactivity for $\mathrm{p}$-Tie2 decreased in remodeled vessels, but overall Tie 2 mRNA expression did not change. Selective inhibition of Ang2 significantly reduced the decrease in $\mathrm{p}$-Tie2 immunoreactivity and the vascular remodeling during the infection.

Although the amount of Ang2 immunoreactivity per endothelial cell was not noticeably increased, M. pulmonis infection is followed by rapid proliferation of endothelial cells, which results in an increase in the population of endothelial cells and in enlargement of remodeled capillaries and venules. ${ }^{30}$ The estimated twofold increase in number of endothelial cells after infection is in scale with the increase in Ang2 mRNA and is consistent with the similar increase in VE-cadherin shown in Figure 4F.

The early increase in Ang2 expression and reduction in p-Tie2 immunoreactivity after M. pulmonis infection are
M. pulmonis + mAb 3.19 .3

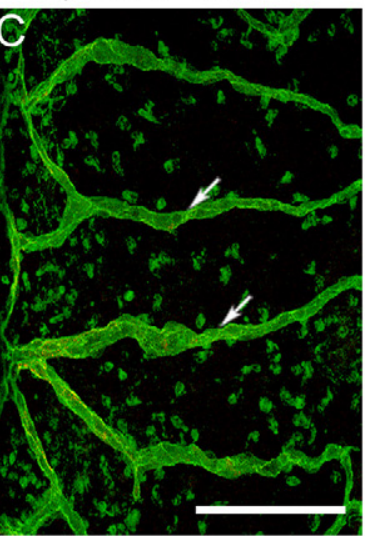

Figure 6. Reduction in vascular remodeling by Ang2 blockade with mAb 3.19.3. A-C: Confocal micrographs of P-selectin immunoreactivity (red) in blood vessels (green, PECAM-1) of tracheal whole mount of pathogen-free mouse and mice infected with $M$. pulmonis for 7 days with concurrent treatment with $10 \mathrm{mg} / \mathrm{kg}$ of isotype control IgG (B) or mAb 3.19.3 (C). Arrows mark regions where vessel measurements were made. D: Diameter of tracheal blood vessels measured over midpoint of cartilage rings in pathogen-free mice and mice treated with IgG or mAb 3.19.3 during 7-day infection. $\mathbf{E}$ and $\mathbf{F}$ : qRT-PCR measurements of expression of PECAM-1 and VE-cadherin (E) or Pselectin and E-selectin (F) in tracheas of infected mice treated with IgG or mAb 3.19.3 for 7 days. Values after Ang2 blockade by mAb 3.19 .3 were significantly less. ${ }^{*} P<0.05$ compared to pathogenfree; ${ }^{* *} P<0.05$ compared to infected mice treated with IgG. Scale bars $=100 \mu \mathrm{m}$. consistent with the contribution of Ang2 to the suppression of Tie2 phosphorylation during the remodeling process. In support of this, we found that inhibition of Ang2 by two different Ang2 function-blocking antibodies reduced vascular remodeling after infection and accompanying changes in expression of PECAM-1, VE-cadherin, P-selectin, and E-selectin, and in leukocyte influx.

The angiopoietins have been implicated in the regulation vascular permeability in inflammation. ${ }^{5,41,42}$ Mucosal edema is a feature of chronic inflammatory airway diseases in general and in M. pulmonis infection in particular. ${ }^{30,43}$ The rate of leakage after $M$. pulmonis infection is small compared to that after bradykinin, histamine, or substance $P$, and therefore difficult to measure. ${ }^{30}$ However, the impact of leakage after infection is potentially much greater because it is continuous and does not resolve spontaneously, whereas the half-life of leakage after bradykinin, histamine, or substance $P$ is only a few minutes. ${ }^{42}$ The reversibility of the leakage in sustained inflammation by manipulation of angiopoietin/Tie2 signaling is a promising direction for future research.

Both function-blocking antibodies bind Ang2 with high affinity (Thurston et al, unpublished data and Brown et al, $2010^{31}$ ), but attributing this effect exclusively to Ang2 blockade is dependent on the selectivity of the antibodies. Because the assays used to test antibody specificity have limitations, a minor contribution of inhibitory activity on Ang1 or other angiopoietin cannot be excluded. The two blocking antibodies reduced expression of adhesion 
Pathogen-free

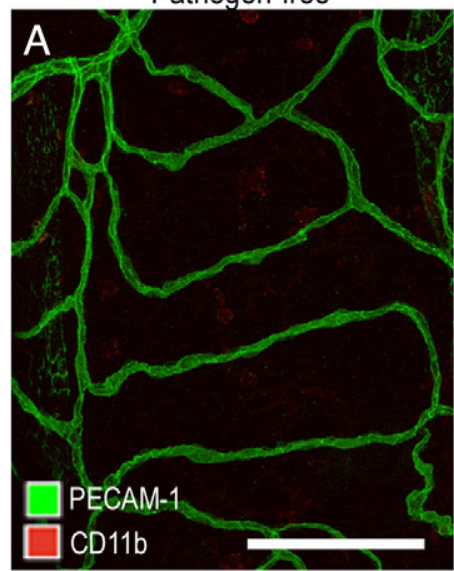

D CD11b immunoreactivity $E$

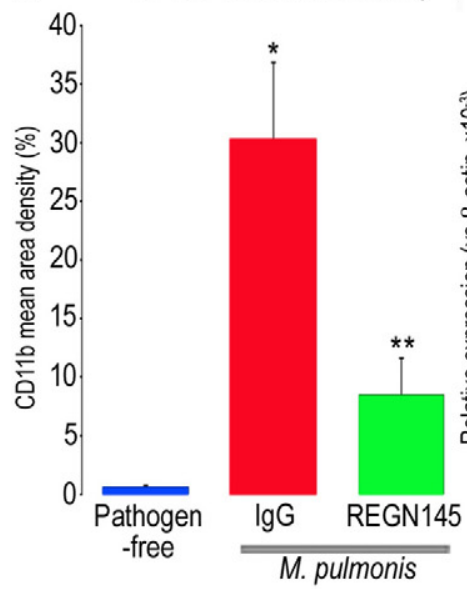

M. pulmonis $+\lg G$

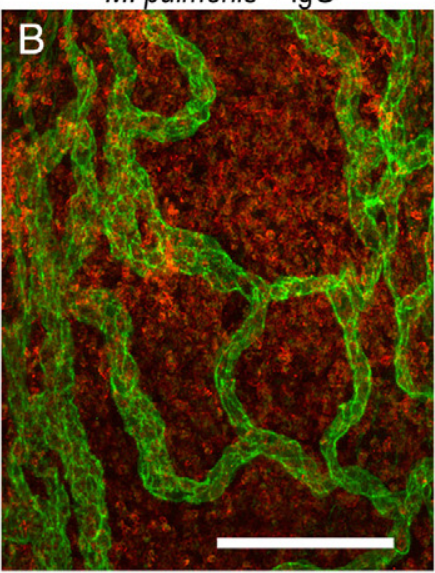

\section{$\mathrm{E}$}

CD11b expression

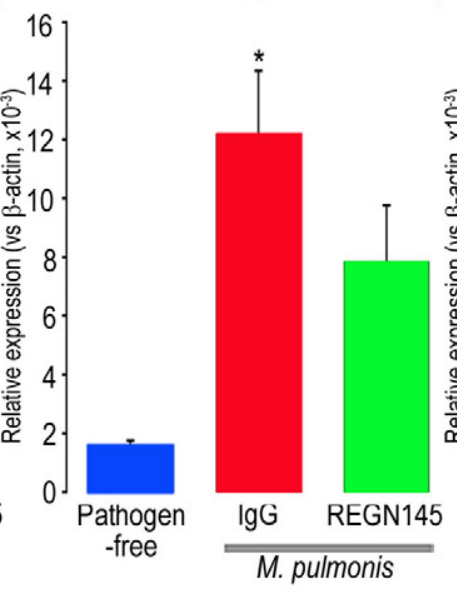

M. pulmonis + REGN145

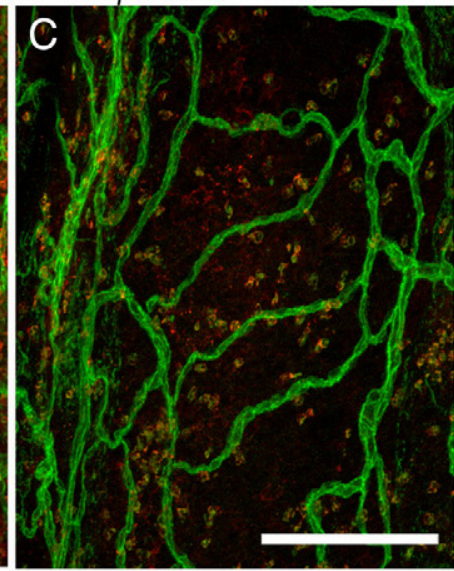

$\mathrm{F}$

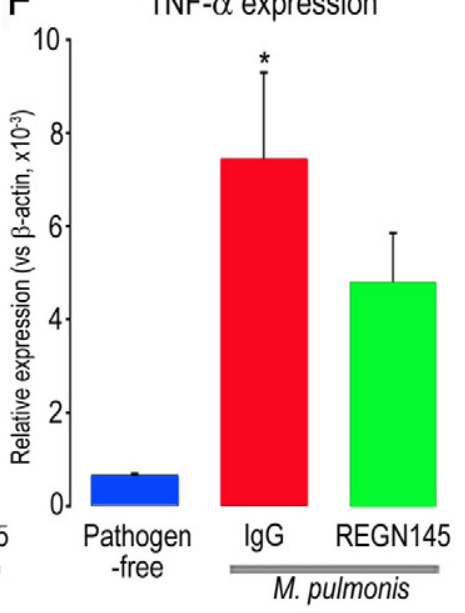

\section{G}

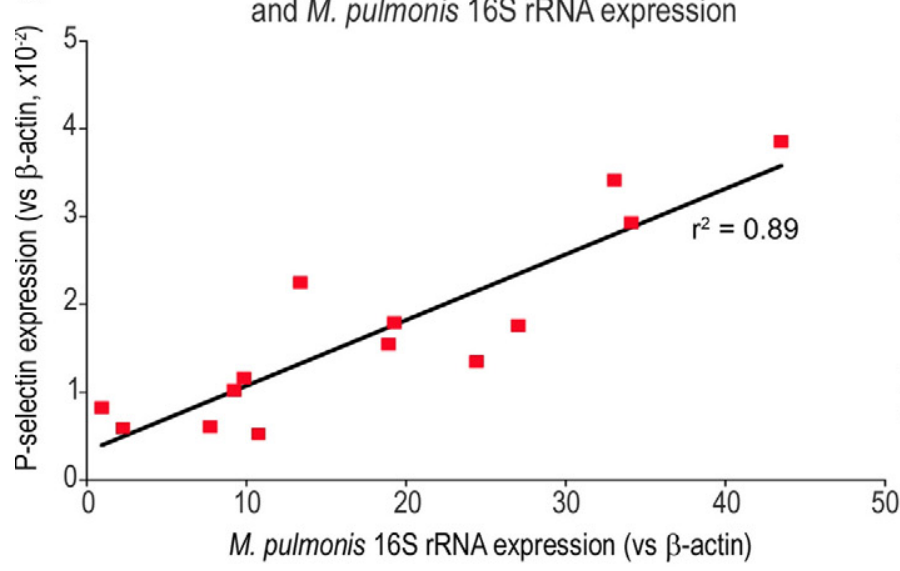

\section{H M. pulmonis}

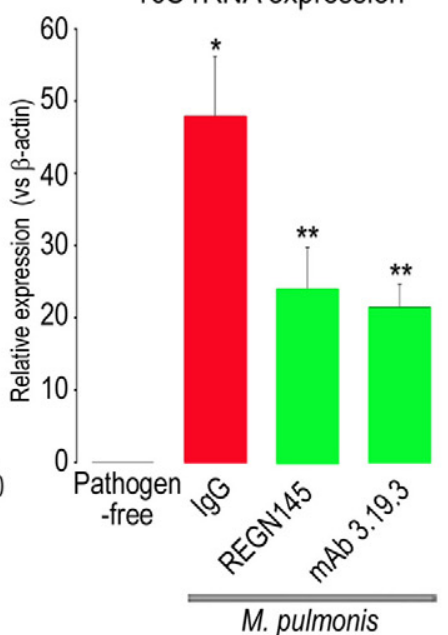

Figure 7. Reduction in leukocyte influx by Ang2 blockade during infection. A-C: Confocal micrographs of leukocytes (red, CD11b) and blood vessels (green, PECAM-1) in regions over cartilage in tracheal whole mount of pathogen-free mouse and mice with $M$. pulmonis infection for 7 days and concurrent treatment with $5 \mathrm{mg} / \mathrm{kg}$ of isotype control IgG (B) or REGN145 (C). D: Fractional area of CD11b immunoreactivity in mucosa over cartilages of pathogen-free mice and infected mice treated with IgG or REGN145. E and F: qRT-PCR measurements of expression of CD11b (E), TNF- $\alpha$ (F) in tracheas of pathogen-free mice and infected mice treated with IgG or REGN145 for 7 days, showing significantly lower values after REGN145 $(N=15)$. G: Linear regression $\left(r^{2}=0.89\right)$ of P-selectin expression and $M$. pulmonis $16 \mathrm{~S}$ rRNA expression measured by qRT-PCR in tracheas of mice infected for 7 days. H: qRT-PCR measurements of $M$. pulmonis $16 \mathrm{~S}$ rRNA expression in tracheas of pathogen-free mice and mice infected and treated for 7 days with control IgG, REGN145, or mAb 3.19.3. ${ }^{*} P<0.05$ compared to pathogen-free; ${ }^{* *} P<0.05$ compared to infected mice treated with IgG. Scale bars $=150 \mu \mathrm{m}$. 
molecules and infection severity to a similar extent. REGN145 led to somewhat greater reduction in capillary diameter than mAb 3.19.3, perhaps because of differences in affinity, pharmacokinetics, or selectivity. Nonetheless, the striking similarity of the effects of the two antibodies during $M$. pulmonis infection argue that Ang2 promotes vascular remodeling in this model.

Our finding of uniform $\mathrm{p}$-Tie2 immunoreactivity on blood vessels of normal tracheas supports the concept that Tie2 is phosphorylated in normal, stable endothelial cells of adult blood vessels. ${ }^{44}$ The results linking increased Ang2 expression to reduced Tie2 phosphorylation after $M$. pulmonis infection, and conversely, linking Ang2 blockade to less reduction of p-Tie2, suggest that Ang2 acts as a Tie2 antagonist and that loss of Tie2 phosphorylation renders the vasculature more responsive to inflammatory cytokines in infected airways. This mechanism would explain how the actions of TNF- $\alpha$ and Ang2 cooperate in promoting the remodeling of capillaries into venules after $M$. pulmonis infection. ${ }^{8}$

How can the decrease in Ang1 mRNA found at 7 days after infection be reconciled with the increase in Ang1 protein in a previous study? ${ }^{28}$ Several lines of evidence help to explain the difference. M. pulmonis infection leads to a massive influx of leukocytes into the airways and lungs. ${ }^{30}$ Most of the Ang1 protein detected as immunoreactivity at 7 days is associated with neutrophils, whereas Ang2 immunoreactivity is in endothelial cells. ${ }^{28}$ Similarly, purified circulating human neutrophils contain Ang1-but not Ang2. ${ }^{45}$

The earlier study found an increase in Ang1 protein assessed in Western blots, ${ }^{28}$ and the present study found a decrease in Ang1 mRNA expression measured by qRTPCR. Ang1 is likely to be stored in neutrophils as previously synthesized protein and not accompanied by a corresponding level of expression of Ang 1 mRNA. Ang1 and VEGF in circulating human neutrophils are released in equal amounts by phorbol myristate acetate stimulation, but expression of Ang1 mRNA is 92\% lower than expression of VEGF mRNA. ${ }^{45}$ Neutrophil $\beta$-granule-associated proteins elastase and myeloperoxidase are synthesized during differentiation and stored until secretion at sites of inflammation. ${ }^{46,47}$ Ang 1 mRNA expression may be similarly down-regulated during the final steps of neutrophil maturation. The release of Ang1 protein from neutrophils differs from secretion of VEGF and other proteins in $\beta$-granules, because Ang1 is cytosolic instead of in granules and its release is neither calcium dependent nor evoked by TNF- $\alpha$ or other neutrophil-activating cytokines. ${ }^{45}$ Vascular remodeling after infection was associated with increased Ang2 expression and decreased Tie2 phosphorylation, which are consistent with Ang2mediated inactivation of Tie2 signaling as a trigger for the vascular remodeling. If, when, where, and how much Ang1 is released and the contribution of neutrophil Ang1 to the response remain to be determined.

TNF- $\alpha$ may promote the increase in Ang2 expression after M. pulmonis infection. TNF- $\alpha$ is known to up-regulate Ang2 expression in endothelial cells ${ }^{48,49}$ and to increase rapidly in expression after $M$. pulmonis infection. ${ }^{8}$ TNF- $\alpha$ can also induce expression of adhesion molecules involved in leukocyte influx via Ang2 activation. ${ }^{11,50}$

Levels of Ang2 in blood or other body fluids increase in multiple diseases. Higher levels of Ang2 in airway fluid or blood are associated with more severe disease in patients with acute lung injury and in infants that develop bronchopulmonary dysplasia. ${ }^{40,51}$ Higher levels of Ang2 in sputum correlate with more airway vascular leakiness in asthma. ${ }^{52,53}$ High blood levels of Ang2 correlate with disease severity or poor outcome in patients with sepsis, ${ }^{54,55}$ systemic lupus erythematosus, ${ }^{56}$ inflammatory bowel disease, ${ }^{57}$ and malaria. ${ }^{58}$

Ang2 blockade reduced the load of $M$. pulmonis organisms. The anti-inflammatory action of dexamethasone similarly reduces the load of $M$. pulmonis in the airways. ${ }^{59}$ Both of these actions reflect the link between conditions that influence the growth of the organisms and the magnitude of the inflammatory response. They also fit with the reciprocal interdependence of the severity of $M$. pulmonis infection and magnitude of the inflammatory response. ${ }^{60,61}$ Pro-inflammatory factors exacerbate the infection, and anti-inflammatory factors reduce it.

In conclusion, our results show that inhibition of Ang2 stabilizes Tie2 phosphorylation in endothelial cells, reduces vascular remodeling and expansion of venules that support leukocyte influx, and reduces the overall severity of $M$. pulmonis infection. These findings warrant further studies to develop a better understanding of the favorable actions of Ang2 inhibitors in airway inflammation.

\section{Acknowledgments}

We thank DongJi Zhang and Nigel Killeen for production of the M. pulmonis stock and Peter Baluk for helpful discussions.

\section{References}

1. Wilson JW, Hii S: The importance of the airway microvasculature in asthma. Curr Opin Allergy Clin Immunol 2006, 6:51-55

2. James AL, Pare PD, Hogg JC: The mechanics of airway narrowing in asthma. Am Rev Respir Dis 1989, 139:242-246

3. Kanazawa $\mathrm{H}$ : Role of vascular endothelial growth factor in the pathogenesis of chronic obstructive pulmonary disease. Med Sci Monit 2007, 13:RA189-RA195

4. de Boer WI, Alagappan VK, Sharma HS: Molecular mechanisms in chronic obstructive pulmonary disease: potential targets for therapy. Cell Biochem Biophys 2007, 47:131-148

5. McDonald DM: Angiogenesis and remodeling of airway vasculature in chronic inflammation. Am J Respir Crit Care Med 2001, 164:S39-S45

6. Baluk P, Lee CG, Link H, Ator E, Haskell A, Elias JA, McDonald DM Regulated angiogenesis and vascular regression in mice overexpressing vascular endothelial growth factor in airways. Am J Pathol 2004, 165:1071-1085

7. Baluk P, Tammela T, Ator E, Lyubynska N, Achen MG, Hicklin DJ, Jeltsch M, Petrova TV, Pytowski B, Stacker SA, Yla-Herttuala S, Jackson DG, Alitalo K, McDonald DM: Pathogenesis of persistent lymphatic vessel hyperplasia in chronic airway inflammation. J Clin Invest 2005, 115:247-257

8. Baluk P, Yao LC, Feng J, Romano T, Jung SS, Schreiter JL, Yan L, Shealy DJ, McDonald DM: TNF-alpha drives remodeling of blood vessels and lymphatics in sustained airway inflammation in mice. J Clin Invest 2009, 119:2954-2964 
9. Mounzer RH, Svendsen OS, Baluk P, Bergman CM, Padera TP, Wiig $\mathrm{H}$, Jain RK, McDonald DM, Ruddle NH: Lymphotoxin-alpha contributes to lymphangiogenesis. Blood 2010, 116:2173-2182

10. Eklund L, Olsen BR: Tie receptors and their angiopoietin ligands are context-dependent regulators of vascular remodeling. Exp Cell Res 2006, 312:630-641

11. Fiedler U, Augustin HG: Angiopoietins: a link between angiogenesis and inflammation. Trends Immunol 2006, 27:552-558

12. Davis S, Aldrich TH, Jones PF, Acheson A, Compton DL, Jain V, Ryan TE, Bruno J, Radziejewski C, Maisonpierre PC, Yancopoulos GD: Isolation of angiopoietin-1, a ligand for the TIE2 receptor, by secretion-trap expression cloning. Cell 1996, 87:1161-1169

13. London NR, Whitehead KJ, Li DY: Endogenous endothelial cell signaling systems maintain vascular stability. Angiogenesis 2009, 12:149-158

14. Simoes DC, Vassilakopoulos T, Toumpanakis D, Petrochilou K, Roussos C, Papapetropoulos A: Angiopoietin-1 protects against airway inflammation and hyperreactivity in asthma. Am J Respir Crit Care Med 2008, 177:1314-1321

15. Lee KS, Lee KY, Kim SR, Park HS, Park SJ, Min KH, Cho CH, Koh GY, Lee YC: Blockade of airway inflammation and hyper-responsiveness by an angiopoietin-1 variant, COMP-Ang1. Exp Mol Med 2007, 39:733-745

16. Pizurki L, Zhou Z, Glynos K, Roussos C, Papapetropoulos A: Angiopoietin-1 inhibits endothelial permeability, neutrophil adherence and IL-8 production. Br J Pharmacol 2003, 139:329-336

17. Kim I, Moon SO, Park SK, Chae SW, Koh GY: Angiopoietin-1 reduces VEGF-stimulated leukocyte adhesion to endothelial cells by reducing ICAM-1, VCAM-1, and E-selectin expression. Circ Res 2001, 89:477-479

18. Maisonpierre PC, Suri C, Jones PF, Bartunkova S, Wiegand SJ, Radziejewski C, Compton D, McClain J, Aldrich TH, Papadopoulos N, Daly TJ, Davis S, Sato TN, Yancopoulos GD: Angiopoietin-2, a natural antagonist for Tie2 that disrupts in vivo angiogenesis. Science 1997, 277:55-60

19. Fiedler U, Scharpfenecker M, Koidl S, Hegen A, Grunow V, Schmidt JM, Kriz W, Thurston G, Augustin HG: The Tie-2 ligand angiopoietin-2 is stored in and rapidly released upon stimulation from endothelial cell Weibel-Palade bodies. Blood 2004, 103:4150-4156

20. Makinde TO, Agrawal DK: Increased expression of angiopoietins and Tie2 in the lungs of chronic asthmatic mice. Am J Respir Cell Mol Biol 2010, DOI:10.1165/rcmb.2009-03300C

21. Daly C, Pasnikowski E, Burova E, Wong V, Aldrich TH, Griffiths J, loffe E, Daly TJ, Fandl JP, Papadopoulos N, McDonald DM, Thurston G, Yancopoulos GD, Rudge JS: Angiopoietin-2 functions as an autocrine protective factor in stressed endothelial cells. Proc Natl Acad Sci USA 2006, 103:15491-15496

22. Yuan HT, Khankin EV, Karumanchi SA, Parikh SM: Angiopoietin 2 is a partial agonist/antagonist of Tie2 signaling in the endothelium. Mol Cell Biol 2009, 29:2011-2022

23. Kim KE, Cho $\mathrm{CH}$, Kim HZ, Baluk P, McDonald DM, Koh GY: In vivo actions of angiopoietins on quiescent and remodeling blood and lymphatic vessels in mouse airways and skin. Arterioscler Thromb Vasc Biol 2007, 27:564-570

24. Lemieux C, Maliba R, Favier J, Theoret JF, Merhi Y, Sirois MG: Angiopoietins can directly activate endothelial cells and neutrophils to promote proinflammatory responses. Blood 2005, 105:1523-1530

25. Sturn DH, Feistritzer C, Mosheimer BA, Djanani A, Bijuklic K, Patsch JR, Wiedermann CJ: Angiopoietin affects neutrophil migration. Microcirculation 2005, 12:393-403

26. Maliba R, Lapointe S, Neagoe PE, Brkovic A, Sirois MG: Angiopoietins-1 and -2 are both capable of mediating endothelial PAF synthesis: intracellular signalling pathways. Cell Signal 2006, 18:1947-1957

27. Maliba R, Brkovic A, Neagoe PE, Villeneuve LR, Sirois MG: Angiopoietin-mediated endothelial P-selectin translocation: cell signaling mechanisms. J Leukoc Biol 2008, 83:352-360

28. Fuxe J, Lashnits E, O'Brien S, Baluk P, Tabruyn SP, Kuhnert F, Kuo C, Thurston G, McDonald DM: Angiopoietin/Tie2 signaling transforms capillaries into venules primed for leukocyte trafficking in airway inflammation. Am J Pathol 2010, 176:2009-2018

29. Davidson MK, Lindsey JR, Parker RF, Tully JG, Cassell GH: Differences in virulence for mice among strains of Mycoplasma pulmonis. Infect Immun 1988, 56:2156-2162

30. Ezaki T, Baluk P, Thurston G, La Barbara A, Woo C, McDonald DM:
Time course of endothelial cell proliferation and microvascular remodeling in chronic inflammation. Am J Pathol 2001, 158:2043-2055

31. Brown J, Cao AZ, Pinzon-Ortiz M, Kendrew J, Reimer C, Wen S, Zhou QJ, Tabrizi M, Emery S, McDermott B, Pablo L, McCoon P, Bedian V, Blakey DC: A human monoclonal anti-ang2 antibody leads to broad antitumor activity in combination with VEGF inhibitors and chemotherapy agents in preclinical models. Mol Cancer Ther 2010, 9:145-156

32. Thurston G, Wang Q, Baffert F, Rudge J, Papadopoulos N, JeanGuillaume D, Wiegand S, Yancopoulos GD, McDonald DM: Angiopoietin 1 causes vessel enlargement, without angiogenic sprouting, during a critical developmental period. Development 2005, 132:3317-3326

33. Baffert F, Thurston G, Rochon-Duck M, Le T, Brekken R, McDonald DM: Age-related changes in vascular endothelial growth factor dependency and angiopoietin-1-induced plasticity of adult blood vessels. Circ Res 2004, 94:984-992

34. Thurston G, Murphy TJ, Baluk P, Lindsey JR, McDonald DM: Angiogenesis in mice with chronic airway inflammation: strain-dependent differences. Am J Pathol 1998, 153:1099-1112

35. Thurston G, Maas K, Labarbara A, McLean JW, McDonald DM: Microvascular remodelling in chronic airway inflammation in mice. Clin Exp Pharmacol Physiol 2000, 27:836-841

36. Thurston G, Suri C, Smith K, McClain J, Sato TN, Yancopoulos GD, McDonald DM: Leakage-resistant blood vessels in mice transgenically overexpressing angiopoietin-1. Science 1999, 286:2511-2514

37. Suri C, Jones PF, Patan S, Bartunkova S, Maisonpierre PC, Davis S, Sato TN, Yancopoulos GD: Requisite role of angiopoietin-1, a ligand for the TIE2 receptor, during embryonic angiogenesis. Cell 1996, $87: 1171-1180$

38. Gale NW, Thurston G, Hackett SF, Renard R, Wang Q, McClain J, Martin C, Witte C, Witte MH, Jackson D, Suri C, Campochiaro PA, Wiegand SJ, Yancopoulos GD: Angiopoietin-2 is required for postnatal angiogenesis and lymphatic patterning, and only the latter role is rescued by Angiopoietin-1. Dev Cell 2002, 3:411-423

39. McDonald DM: Angiogenesis and vascular remodeling in inflammation and cancer: Biology and architecture of the vasculature. Edited by WD Figg and J Folkman. New York, Springer, 2008, pp 15-31

40. Bhandari V, Choo-Wing R, Lee CG, Zhu Z, Nedrelow JH, Chupp GL, Zhang X, Matthay MA, Ware LB, Homer RJ, Lee PJ, Geick A, de Fougerolles AR, Elias JA: Hyperoxia causes angiopoietin 2-mediated acute lung injury and necrotic cell death. Nat Med 2006, 12:1286-1293

41. Thurston G, Rudge JS, loffe E, Zhou H, Ross L, Croll SD, Glazer N, Holash J, McDonald DM, Yancopoulos GD: Angiopoietin-1 protects the adult vasculature against plasma leakage. Nat Med 2000, 6:460-463

42. Baffert F, Le T, Thurston G, McDonald DM: Angiopoietin-1 decreases plasma leakage by reducing number and size of endothelial gaps in venules. Am J Physiol Heart Circ Physiol 2006, 290:H107-H118

43. Kwan ML, Gomez AD, Baluk P, Hashizume H, McDonald DM: Airway vasculature after mycoplasma infection: chronic leakiness and selective hypersensitivity to substance P. Am J Physiol Lung Cell Mol Physiol 2001, 280:L286-L297

44. Wong AL, Haroon ZA, Werner S, Dewhirst MW, Greenberg CS, Peters KG: Tie2 expression and phosphorylation in angiogenic and quiescent adult tissues. Circ Res 1997, 81:567-574

45. Neagoe PE, Brkovic A, Hajjar F, Sirois MG: Expression and release of angiopoietin-1 from human neutrophils: intracellular mechanisms. Growth Factors 2009, 27:335-344

46. Fouret P, du Bois RM, Bernaudin JF, Takahashi H, Ferrans VJ, Crystal RG: Expression of the neutrophil elastase gene during human bone marrow cell differentiation. J Exp Med 1989, 169:833-845

47. Cowland JB, Borregaard N: The individual regulation of granule protein mRNA levels during neutrophil maturation explains the heterogeneity of neutrophil granules. J Leukoc Biol 1999, 66:989-995

48. Kim I, Kim JH, Ryu YS, Liu M, Koh GY: Tumor necrosis factor-alpha upregulates angiopoietin-2 in human umbilical vein endothelial cells. Biochem Biophys Res Commun 2000, 269:361-365

49. Hegen A, Koidl S, Weindel K, Marme D, Augustin HG, Fiedler U: Expression of angiopoietin-2 in endothelial cells is controlled by positive and negative regulatory promoter elements. Arterioscler Thromb Vasc Biol 2004, 24:1803-1809

50. Fiedler U, Reiss Y, Scharpfenecker M, Grunow V, Koidl S, Thurston G, Gale NW, Witzenrath M, Rosseau S, Suttorp N, Sobke A, Herrmann M, 
Preissner KT, Vajkoczy P, Augustin HG: Angiopoietin-2 sensitizes endothelial cells to TNF-alpha and has a crucial role in the induction of inflammation. Nat Med 2006, 12:235-239

51. Aghai ZH, Faqiri S, Saslow JG, Nakhla T, Farhath S, Kumar A, Eydelman R, Strande L, Stahl G, Leone P, Bhandari V: Angiopoietin 2 concentrations in infants developing bronchopulmonary dysplasia: attenuation by dexamethasone. J Perinatol 2007, 28:149-155

52. Kanazawa H, Nomura S, Asai K: Roles of angiopoietin-1 and angiopoietin-2 on airway microvascular permeability in asthmatic patients. Chest 2007, 131:1035-1041

53. Kanazawa H, Asai K, Tochino Y, Kyoh S, Kodama T, Hirata K: Increased levels of angiopoietin-2 in induced sputum from smoking asthmatic patients. Clin Exp Allergy 2009, 39:1330-1337

54. Siner JM, Bhandari V, Engle KM, Elias JA, Siegel MD: Elevated serum angiopoietin 2 levels are associated with increased mortality in sepsis. Shock 2009, 31:348-353

55. Kumpers P, van Meurs M, David S, Molema G, Bijzet J, Lukasz A, Biertz F, Haller H, Zijlstra JG: Time course of angiopoietin-2 release during experimental human endotoxemia and sepsis. Crit Care 2009, 13:R64

56. Kumpers P, David S, Haubitz M, Hellpap J, Horn R, Brocker V,
Schiffer M, Haller H, Witte T: The Tie2 receptor antagonist angiopoietin 2 facilitates vascular inflammation in systemic lupus erythematosus. Ann Rheum Dis 2009, 68:1638-1643

57. Koutroubakis IE, Xidakis C, Karmiris K, Sfiridaki A, Kandidaki E, Kouroumalis EA: Potential role of soluble angiopoietin-2 and Tie-2 in patients with inflammatory bowel disease. Eur J Clin Invest 2006, 36:127-132

58. Yeo TW, Lampah DA, Gitawati R, Tjitra E, Kenangalem E, Piera K, Price RN, Duffull SB, Celermajer DS, Anstey NM: Angiopoietin-2 is associated with decreased endothelial nitric oxide and poor clinical outcome in severe falciparum malaria. Proc Natl Acad Sci USA 2008, 105:17097-17102

59. Yao LC, Baluk P, Feng J, McDonald DM: Steroid-resistant lymphatic remodeling in chronically inflamed mouse airways. Am J Pathol 2010, 176:1525-1541

60. Schoeb TR, Davidson MK, Lindsey JR: Intracage ammonia promotes growth of Mycoplasma pulmonis in the respiratory tract of rats. Infect Immun 1982, 38:212-217

61. Pinson DM, Schoeb TR, Lin SL, Lindsey JR: Promotion of Mycoplasma pulmonis growth in rat tracheal organ cultures by ammonium chloride. Lab Anim Sci 1988, 38:143-147 